\title{
Phenology and water relations of eight woody species in the Coronation Garden of Kirtipur, central Nepal
}

\author{
Bharat B Shrestha*, Yadav Uprety', Keshav Nepal ${ }^{2}$, Sandhya Tripathi ${ }^{3}$, and Pramod K Jha \\ Central Department of Botany, Tribhuvan University, Kathmandu, NEPAL \\ ${ }^{1}$ Present address: Department of Human Ecology, Vrije University, Brussel, BELGIUM \\ ${ }^{2}$ Present address: Institute of Biomolecular Reconstruction, Somoom University, KOREA \\ ${ }^{3}$ Present address: Prithvi Narayan Campus, Tribhuvan University, Pokhara, NEPAL \\ * For correspondence, email: bhabashre@yahoo.com
}

\begin{abstract}
Phenological activities of eight woody species planted in Kirtipur (central Nepal) were examined, each for one dry season between September 2001 and June 2003. From Pressure Volume (P-V) analysis, we determined relative water content at zero turgor $\left(\mathrm{RWC}_{\mathrm{z}}\right)$, osmotic potential at zero turgor $\left(\psi_{\mathrm{sz}}\right)$ and full turgor $\left(\psi_{\mathrm{sf}}\right)$, and bulk modulus of elasticity $(\varepsilon)$ once a month through the course of dry season. Both evergreen species (Cotoneaster bacillaris Wall., Quercus lanata Sm., Ligustrum confusum Decne., Woodfordia fruticosa (L.) Kurz.) and deciduous species (Celtis australis Linn., Alnus nepalensis D.Don., Bauhinia variegata Linn. and Lagerstroemia indica Linn.) put out their new leaves during the dry summer when day length and temperature were increasing. Generally, bud break coincided with concentrated leaf fall during the dry summer and the leaf fall reduced total leaf area to its lowest value. The deciduous species were leafless for one to three months, followed by a prolonged period of leaf production and shoot elongation. Evergreen and deciduous species manifested distinct adaptive strategies to water deficit. Evergreens can reduce osmotic potential $\left(\psi_{\mathrm{s}}\right)$ to its low value and maintain proper water potential $(\psi)$ gradient from soil to plant, which facilitates absorption of water during dry season. Elastic tissue in deciduous species is coupled with leaf shedding during the dry season; both factors may help maintain proper $\psi_{\mathrm{s}}$ for new growth during dry period. One evergreen species (Woodfordia fruticosa) and three deciduous species (Celtis australis, Bauhinia variegata and Lagerstroemia indica) have inherently high dehydration tolerance due to their elastic tissue. During drought there has been osmotic adjustment in Quercus lanata, and elastic adjustment in Ligustrum confusum, Celtis australis and Lagerstroemia indica.
\end{abstract}

Key words: Himalayas, Pressure Volume (P-V) curve, relative water content (RWC), osmotic adjustment, elastic adjustment

Phenology, the distribution of plant activities in time, is highly correlated with seasonal changes in water status of trees (Borchert 1994a, b). Leaf phenology in both seasonal and non-seasonal environments is a central element in plant strategies for carbon gain (Kikuzawa 1995). The timing of leaf fall and bud break in tropical and subtropical trees is generally determined by plant water status, which in turn is a function of the interaction between the environmental water status and the structural and functional state of the tree (Reich 1994). Seasonal variation in water status not only determines phenology but also the distribution of trees and forest composition (Borchert 1994a, Zobel et al. 2001). Engelbrecht et al. (2007) has shown that differential drought sensitivity shapes plant distribution in tropical forests at both regional and local scales. The role of drought in controlling species distribution and performance is still poorly understood for Himalayan trees, although indirect evidence and existing measurements suggest that tree distribution is strongly related to drought (Zobel and Singh 1995, Tewari 1998, Poudyal et al. 2004, Shrestha et al. 2006a).

In the context of global warming, mountain ecosystems are being affected more than lowlands, and the extent of drought in mountains is likely to increase in the future (Iyngararasan et al. 2002). Alteration in seasonal coordination of photoperiod and thermal regime affects plant performance (Hanninen 1991), competitive relationships among forest trees, and species distribution and abundance (Lechowicz and Koike 1995). Because the water relations of Himalayan tress cannot be accurately understood only by inference from forest studies elsewhere (Zobel et al. 2001) there is a need for detailed study on water relations and their relationships to phenology and adaptation to seasonal drought. Due to the monsoon, Himalayan trees are exposed to drought for several months each year (Zobel and Singh 1997). Despite their unequal leaf life spans, most trees of this region

Himalayan Journal of Sciences 4(6): 49-56, 2007 Available online at www.himjsci.com Copyright@2007 by Himalayan Association for the Advancement of Science 


\begin{tabular}{|c|c|c|}
\hline Name of Species & Family & $\begin{array}{l}\text { Distribu- } \\
\text { tion (masl)* }\end{array}$ \\
\hline \multicolumn{3}{|l|}{ Evergreen species } \\
\hline Cotoneaster bacillaris Wall. & Rosaceae & $1800-2300$ \\
\hline Quercus lanata Sm. & Fagaceae & $450-2600$ \\
\hline Ligustrum confusum Decne. & Oleaceae & $800-2900$ \\
\hline Woodfordia fruticosa (L.) Kurz. & Lythraceae & $200-1800$ \\
\hline \multicolumn{3}{|l|}{ Deciduous species } \\
\hline Celtis australis Linn. & Ulmaceae & $1300-2200$ \\
\hline Alnus nepalensis D.Don. & Betulaceae & $500-2600$ \\
\hline Bauhinia variegata Linn. & Leguminosae & $150-1900$ \\
\hline Lagerstroemia indica Linn. & Lythraceae & $1000-1500$ \\
\hline
\end{tabular}

produce new leaves and flower during the dry summer season just before the June - September wet season (Ralhan et al. 1985, Shrestha et al. 2006b). Although the environment is dry, trees must maintain the proper turgidity required for growth (Hsaio 1973). Tree species may postpone (Shrestha et al. 2006b, Borchert 1994b) or tolerate dehydration by elastic and osmotic adjustment (Grammatikopoulos 1999, Fan et al. 1994, Mainali et al. 2006). In this paper, we have analyzed pressure volume $(\mathrm{P}-\mathrm{V})$ curves of eight woody species, and we consider the connections between water relations parameters (relative water content, osmotic potential, osmotic and elastic adjustment) and phenology, in order to understand species' natural distribution and adaptation to seasonal drought.

\section{Materials and methods}

We selected for study eight woody species (four evergreen and four deciduous, Table 1), all native to Nepal and planted at the Coronation Garden $\left(27^{\circ} 40^{\prime}-27^{\circ} 41^{\prime} \mathrm{N}, 85^{\circ} 16^{\prime}-85^{\circ} 18^{\prime} \mathrm{E}\right.$, elevation 1280-1400 masl), Tribhuvan University (Kirtipur, Kathmandu, Nepal). Nomenclature and altitudinal range of distribution follows Press et al. (2000). Ligustrum confusum and Woodfordia fruticosa are shrubs and the others are trees. Five species (Cotoneaster bacillaris, Quercus lanata, Ligustrum confusum, Woodfordia fruticosa, and Alnus nepalensis) were sampled from September 2001 to June 2002 (Year 1) and the remaining three (Celtis australis, Bauhinia variegata and Lagerstroemia indica) from August 2002 to June 2003 (Year 2). Although the natural habitats of these species range from the tropics to the temperate zone, they have been planted in a subtropical environment at the Coronation Garden. The climate has three distinct seasons: hot and dry summer (February to May), hot and moist rainy season (June to September) and cold and dry winter (October to January). Annual rainfall during the study period was $1872 \mathrm{~mm}$ in 2002 and $1648 \mathrm{~mm}$ in 2003, with about $80 \%$ falling during the rainy season (Figure 1). Temperature and rainfall of Year 1 were not significantly different from those of Year 2 (ANOVA, $\mathrm{p}$ $=0.9$ and 0.8 , respectively). On this basis, we assumed that the year-to-year variation in water relations attributes was statistically insignificant for the study period.

Phenological activities were recorded every month, and

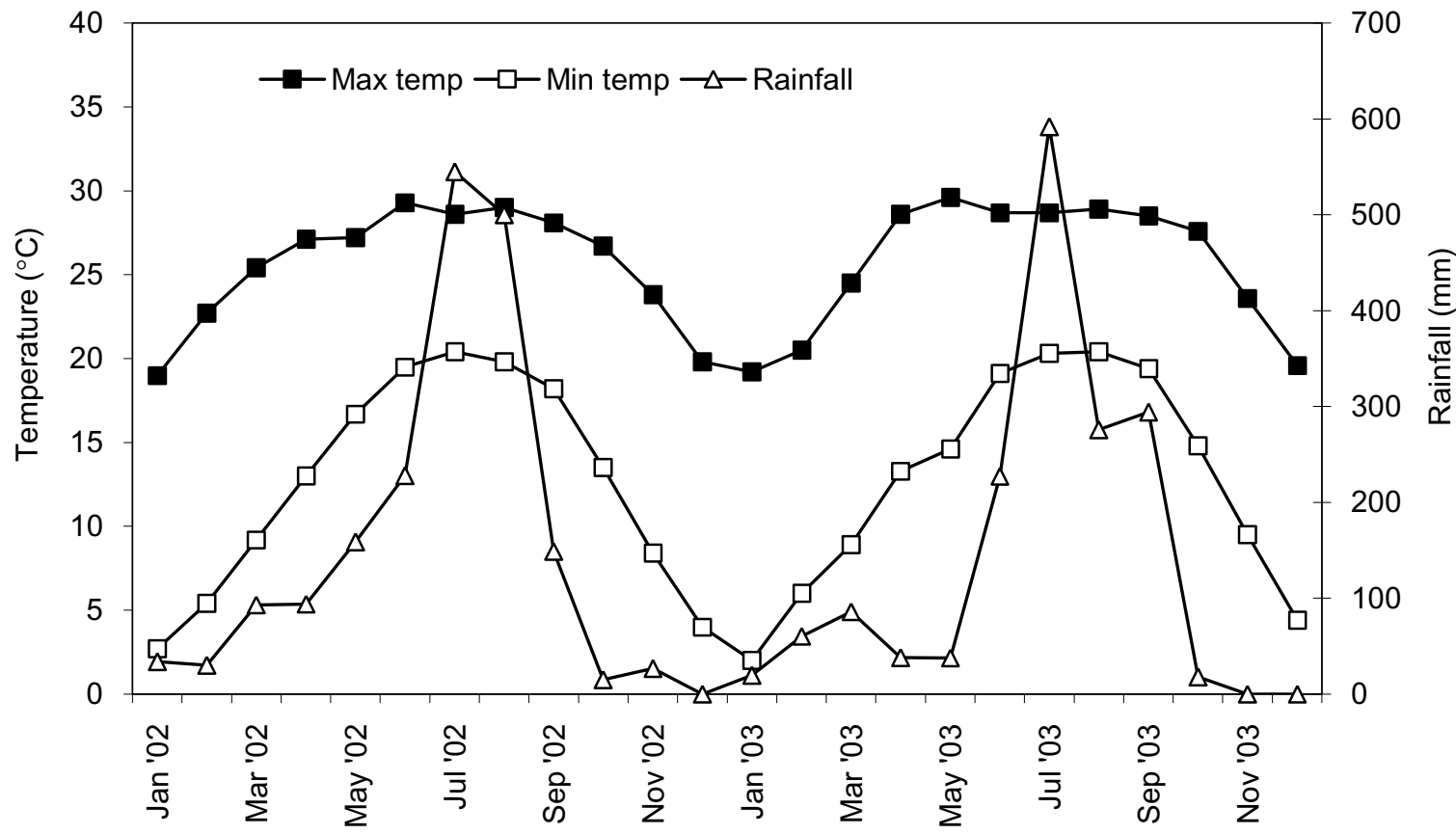

Figure 1. Climate data of Kathmandu valley during the study years (2002 and 2003). (Source: Dept. of Hydrology and Meteorology, Kathmandu, Nepal). The data were recorded at Tribhuvan International Airport (27 $42^{\prime}$ N, $85^{\circ} 22^{\prime}$ E, alt. 1336 masl), which is about $5 \mathrm{~km}$ east of the study site. 
Table 2. Major phenological events of various species. The marked individual of Celtis australis was a sapling; thus it did not produce flowers and fruit. Ligustrum confusum, Woodfordia fruticosa and Bauhinia variegata did not retain fruit, probably due to premature abscission of flowers. Seasons: summer (Feb to May), rainy (Jun to Sep) and winter (Oct to Jan)

\begin{tabular}{lllllll} 
Species name & Bud break & Leaf production & Flowering & Fruiting & Leaf fall & Leafless month(s) \\
Cotoneaster bacillaris & March & Mar-May & Apr-May & May & Mar-Apr & None \\
Quercus lanata & April & May-Jun & Apr-June & Jul & Jan-May & None \\
Ligustrum confusum & April & Apr-Jun & Jun & na & Nov-Apr & None \\
Woodfordia fruticosa & March & Mar-Jun & Apr & na & Nov-Jun & None \\
Celtis australis & March & Mar-Nov & na & na & Nov-Feb & Feb-mid Mar \\
Alnus nepalensis & March & Mar-Sep & Jun & Oct & Jan-Mar & mid Feb-mid Mar \\
Bauhinia variegata & April & Apr-Aug & Mar-May & na & Sep-Feb & Mar-Apr \\
Lagerstroemia indica & March & Mar-Apr & Jun-Aug & Sep & Oct-Dec & Jan-Mar \\
\hline
\end{tabular}

Table 3. Mean values of water relations parameters of evergreen vs. deciduous species and canopy vs. under-canopy species. Also shown is the significance level ( $p$ values) of ANOVA between groups of species ( $\mathrm{N}$ : number of species, and n: total number of samples). Symbols, RWC : Relative water content at zero turgor, $\psi_{\mathrm{sz}}$ : osmotic potential at zero turgor, $\psi_{\mathrm{sf}}$ : osmotic potential at full turgor, $\varepsilon$ : bulk modulus of elasticity

\begin{tabular}{|c|c|c|c|c|c|c|}
\hline Parameters & $\begin{array}{l}\text { Evergreen } \\
(N=4, n=29)\end{array}$ & $\begin{array}{l}\text { Deciduous } \\
(\mathrm{N}=4, \mathrm{n}=35)\end{array}$ & $\begin{array}{l}p \\
\text { value }\end{array}$ & $\begin{array}{l}\text { Canopy species } \\
(\mathrm{N}=4, \mathrm{n}=33)\end{array}$ & $\begin{array}{l}\text { Under canopy sp } \\
(\mathrm{N}=4, \mathrm{n}=31)\end{array}$ & $\begin{array}{l}p \\
\text { value }\end{array}$ \\
\hline $\mathrm{RWC}_{\mathrm{z}}(\%)$ & $82 \pm 6$ & $75 \pm 7$ & 0.000 & $78 \pm 9$ & $79 \pm 5$ & 0.57 \\
\hline$\psi_{\mathrm{sz}}(\mathrm{MPa})$ & $-2.72 \pm 0.78$ & $-1.86 \pm 0.38$ & 0.000 & $-2.43 \pm 0.84$ & $-2.05 \pm 0.53$ & $<0.05$ \\
\hline$\psi_{\mathrm{sf}}(\mathrm{MPa})$ & $-2.10 \pm 0.39$ & $-1.47 \pm 0.31$ & 0.000 & $-1.87 \pm 0.46$ & $-1.6 \pm 0.42$ & $<0.05$ \\
\hline$\varepsilon(\mathrm{MPa})$ & $12 \pm 5$ & $6 \pm 2$ & 0.000 & $10 \pm 6$ & $7 \pm 2$ & $<0.05$ \\
\hline
\end{tabular}

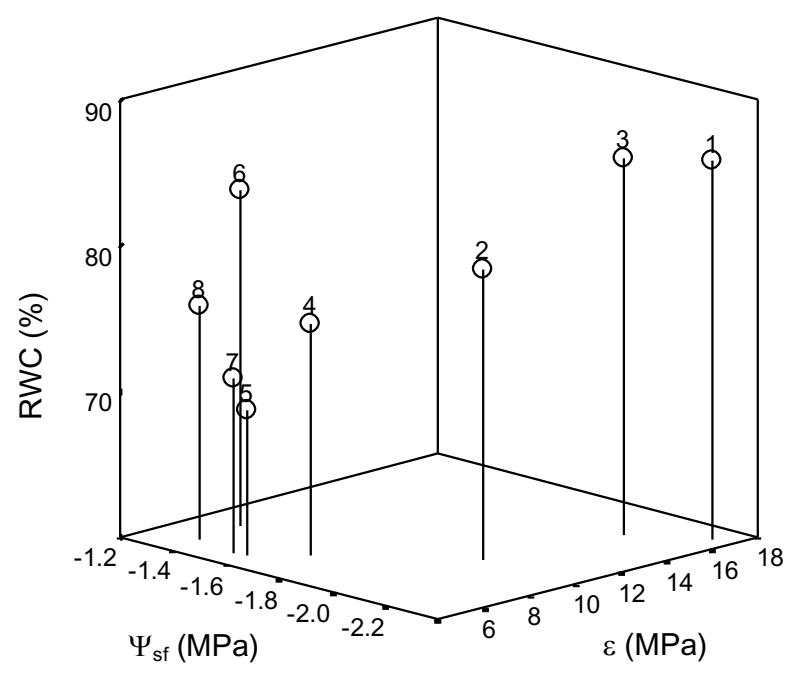

Figure 2. Species level variation of relative water content at zero turgor $\left(\mathrm{RWC}_{\mathrm{z}}, \%\right)$, osmotic potential at full turgor $\left(\psi_{\mathrm{ss}}\right.$, $\mathrm{MPa})$ and bulk modulus of elasticity ( $\varepsilon, \mathrm{MPa})$. Evergreen sp: 1. C. bacillaris, 2. Q. lanata, 3. L. confusum, 4. W. fruticosa; Deciduous sp: 5. C. australis, 6. A. nepalensis, 7. B. variegata, 8. L. indica every two weeks during the period of active growth in three marked individuals of each species. Timing of bud break, leaf production (shoot elongation), flowering, fruiting and leaf fall were recorded. Leaf fall was estimated visually based on fresh leaf litter on the ground and presence of leaves on ultimate branches of the marked individuals. The pressure-volume (P-V) curve was developed by the bench drying method (Pallardy et al. 1991) at Central Department of Botany, Tribhuvan University, Kathmandu. A single sample from the fully exposed side was randomly collected from one of the marked trees of each species and used for the construction of P-V curve on each sampling date, with rehydration period $24 \mathrm{~h}$. During peak rainy months (July-August in Year 1 and August in Year 2), and also when twigs of deciduous species at sampling height were leafless, the plants were not sampled for $\mathrm{P}-\mathrm{V}$ analysis. Relative water content (RWC) and twig water potential ( $\psi$, negative of balance pressure, BP) were determined simultaneously and repeatedly. BP was measured by pressure chamber (Model 1000, PMS Instrument Co., Corvallis, OR USA). From the P-V curve, we estimated RWC at zero turgor $\left(\mathrm{RWC}_{\mathrm{z}}\right)$, osmotic potential at full turgor $\left(\psi_{\mathrm{sf}}\right)$ and zero turgor $\left(\psi_{\mathrm{sz}}\right)$ and bulk modulus of elasticity $(\varepsilon)$.

Statistical analysis We compared mean $\mathrm{RWC}_{\mathrm{z}}, \psi_{\mathrm{sz}}, \psi_{\mathrm{sf}}$, and $\varepsilon$ using Post Hoc Multiple Comparison of one-way ANOVA. ANOVA was also used to compare these parameters for evergreen and deciduous species, shrubs and trees, and 
canopy and under-canopy species. We determined the Pearson correlation (r) among the parameters for each species. We established the relationship between the parameters using linear regression analysis. We used the annual mean $\mathrm{RWC}_{\mathrm{z}}, \psi_{\mathrm{sf}}$ and $\varepsilon$ of individual species to develop a 3-D diagram. SPSS (2001) version 11 for Windows was used for all statistical analysis.

Results

Phenology We found the leaf lifespan of evergreen species

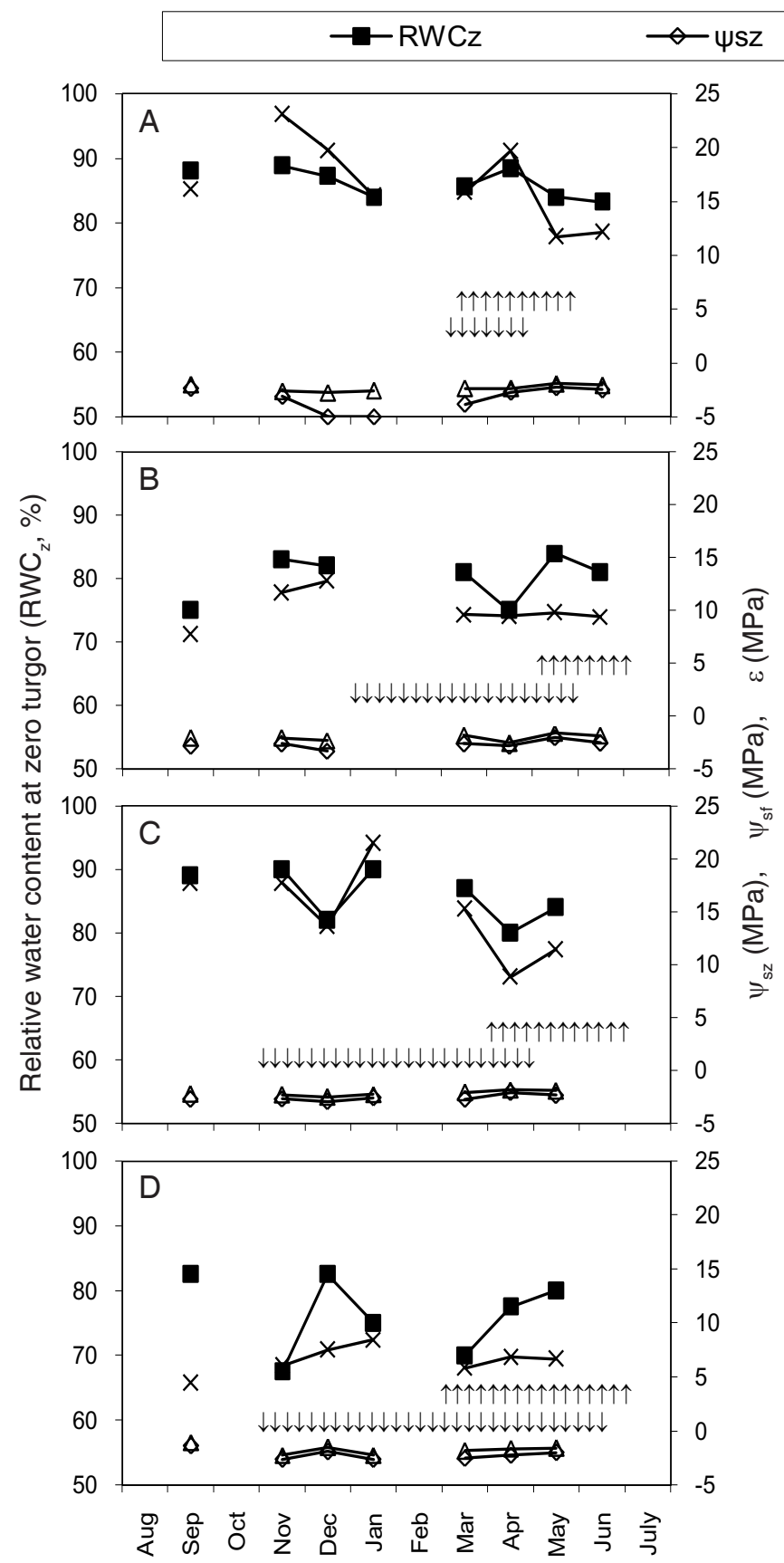

Figure 3. Relative water content at zero turgor $\left(\mathrm{RWC}_{\mathrm{z}}, \%\right)$, bulk modulus of elasticity ( $\varepsilon, \mathrm{MPa})$, osmotic potential at full turgor $\left(\psi_{\mathrm{sf}}, \mathrm{MPa}\right)$ and zero turgor $\left(\psi_{\mathrm{sz}}, \mathrm{MPa}\right)$ for evergreen species (A. Cotoneaster bacillaris B. Quercus lanata C. Ligustrum confusum D. Woodfordia fruticosa). The values were obtained from the pressure volume $(\mathrm{P}-\mathrm{V})$ analysis of a single sample in each sampling date. $(\uparrow \uparrow \uparrow$ indicates leaf production and $\downarrow \downarrow \downarrow$ leaf fall)

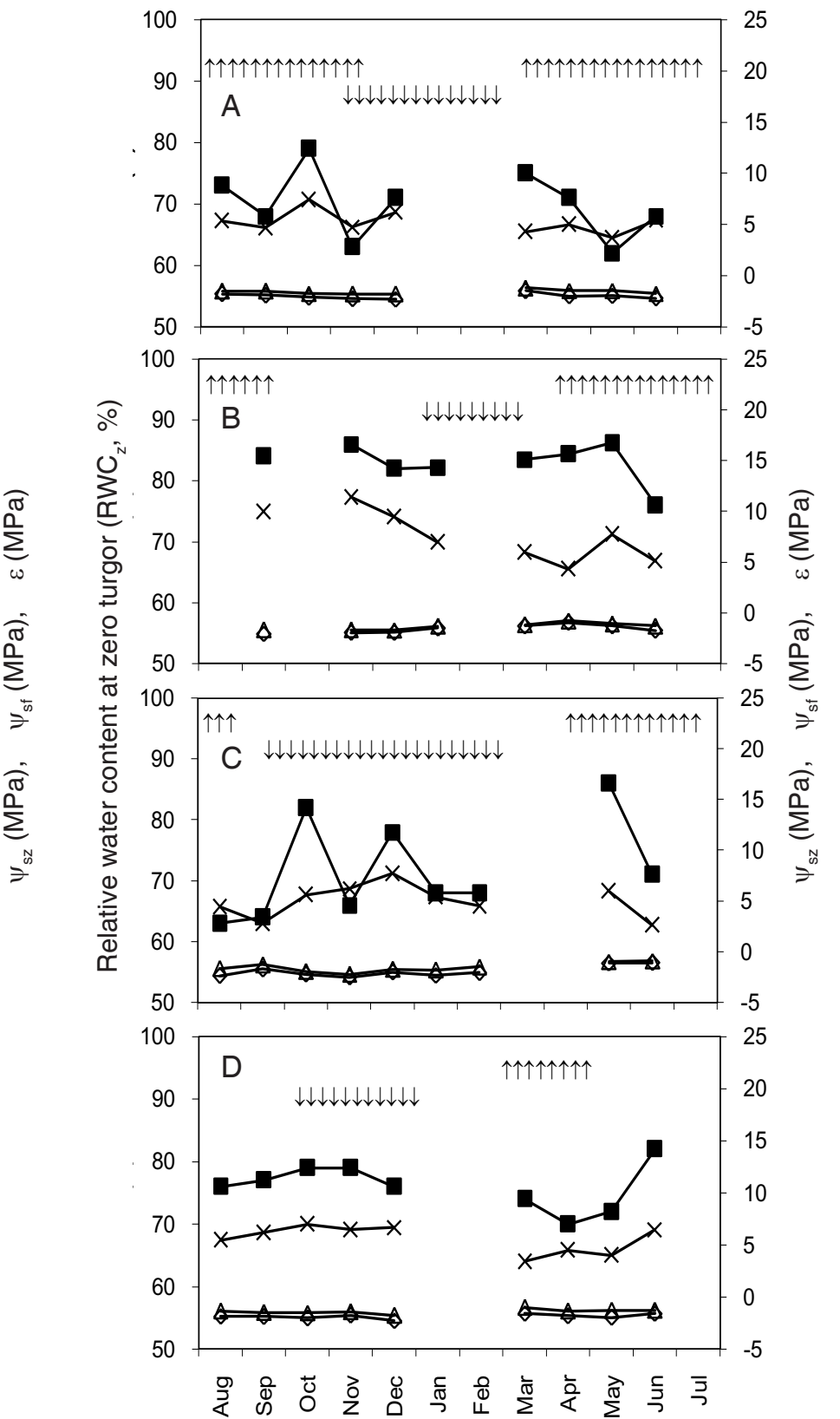

Figure 4. Relative water content at zero turgor $\left(\mathrm{RWC}_{\mathrm{z}}, \%\right)$, bulk modulus of elasticity ( $\varepsilon, \mathrm{MPa})$, osmotic potential at full turgor $\left(\psi_{\mathrm{sf}}, \mathrm{MPa}\right)$ and zero turgor $\left(\psi_{\mathrm{sz}}, \mathrm{MPa}\right)$ for deciduous species (A. Celtis australis B. Alnus nepalensis C. Bauhinia variegata D. Lagerstroemia indica). The values were obtained from the Pressure Volume $(\mathrm{P}-\mathrm{V})$ curve analysis of single sample in each sampling date. ( $\uparrow \uparrow \uparrow$ indicates leaf production and $\downarrow \downarrow \downarrow$ leaf fall) 
Table 4. Annual mean of relative water content at zero turgor $\left(\mathrm{RWC}_{\mathrm{z}}, \%\right)$, summer mean $\mathrm{RWC}_{\mathrm{z}}$, osmotic potential at zero turgor $\left(\psi_{\mathrm{sz}}, \mathrm{MPa}\right)$, osmotic potential at full turgor $\left(\psi_{\mathrm{sf}}, \mathrm{MPa}\right)$, difference between maximum and minimum $\psi_{\text {sf }}\left(\Delta \psi_{\mathrm{sf}}, \mathrm{MPa}\right)$, bulk modulus of elasticity $(\varepsilon, \mathrm{MPa})$ and difference between maximum and minimum $\varepsilon(\Delta \varepsilon, \mathrm{MPa})$. The significant difference between species is shown by different letters $(p=0.05)$. Sampling years $-1: 2002,2: 2003$

\begin{tabular}{|c|c|c|c|c|c|c|c|c|c|}
\hline \multirow[t]{2}{*}{ Species } & \multirow[t]{2}{*}{ Habit* } & \multirow{2}{*}{$\begin{array}{l}\text { Sampling } \\
\text { year }\end{array}$} & \multicolumn{2}{|c|}{ Mean $\mathrm{RWC}_{\mathrm{z}}$} & \multirow[t]{2}{*}{$\psi_{\mathrm{sz}}$} & \multirow[t]{2}{*}{$\psi_{\mathrm{sf}}$} & \multirow[t]{2}{*}{$\Delta \psi_{\text {sf }}$} & \multirow[t]{2}{*}{$\varepsilon$} & \multirow[t]{2}{*}{$\Delta \varepsilon$} \\
\hline & & & Annual & Summer & & & & & \\
\hline Cotoneaster bacillaris $(\mathrm{n}=8)$ & UCT & 1 & $86^{\mathrm{e}}$ & $86^{\mathrm{d}}$ & $-3.35^{\mathrm{a}}$ & $-2.34^{\mathrm{a}}$ & 0.85 & $16.72^{\mathrm{c}}$ & 11.34 \\
\hline Quercus lanata $(\mathrm{n}=7)$ & $\mathrm{CT}$ & 1 & $80^{\mathrm{cd}}$ & $81 b^{c d}$ & $-2.7^{b}$ & $-2.05^{\mathrm{a}}$ & 0.95 & $10.05^{\mathrm{b}}$ & 5.04 \\
\hline Ligustrum confusum $(\mathrm{n}=7)$ & $\mathrm{S}$ & 1 & $86^{\mathrm{e}}$ & $84^{\text {cd }}$ & $-2.56^{\mathrm{bc}}$ & $-2.14^{\mathrm{a}}$ & 0.69 & $15.14^{\mathrm{c}}$ & 12.63 \\
\hline Woodfordia fruticosa $((\mathrm{n}=7)$ & $\mathrm{S}$ & 1 & $76^{\mathrm{bc}}$ & $76^{\mathrm{abc}}$ & $-2.17^{\mathrm{bcd}}$ & $-1.7^{\mathrm{b}}$ & 1.19 & $6.55^{\mathrm{a}}$ & 4.03 \\
\hline Celtis australis $(\mathrm{n}=9)$ & CT & 2 & $70^{\mathrm{a}}$ & $69^{a}$ & $-2.01^{\mathrm{cd}}$ & $-1.58^{\mathrm{bc}}$ & 0.6 & $5.18^{\mathrm{a}}$ & 3.73 \\
\hline Alnus nepalensis $(\mathrm{n}=8)$ & CT & 1 & $83^{\text {de }}$ & $85^{\mathrm{cd}}$ & $-1.62^{\mathrm{d}}$ & $-1.35^{\mathrm{c}}$ & 0.91 & $7.58^{\mathrm{a}}$ & 7.1 \\
\hline Bauhinia variegata $(\mathrm{n}=9)$ & $\mathrm{CT}$ & 2 & $72^{\mathrm{ab}}$ & $76^{\mathrm{abc}}$ & $-1.93^{\mathrm{d}}$ & $-1.54^{\mathrm{bc}}$ & 0.3 & $5.04^{\mathrm{a}}$ & 5.08 \\
\hline Lagerstroemia indica $(\mathrm{n}=9)$ & UCT & 2 & $76^{\mathrm{bc}}$ & $72^{\mathrm{ab}}$ & $-1.85^{\mathrm{d}}$ & $-1.37^{\mathrm{bc}}$ & 0.74 & $5.56^{\mathrm{a}}$ & 3.57 \\
\hline
\end{tabular}

* CT: canopy tree, UCT: under canopy tree, S: shrub. Under canopy trees and shrubs are under canopy species.

Table 5. Pearson correlations (r) among various attributes of plant water relations for each species

\begin{tabular}{|c|c|c|c|c|c|c|c|c|c|}
\hline \multicolumn{2}{|c|}{ Parameters } & \multirow{2}{*}{$\begin{array}{l}\text { Cotoneaster } \\
\text { bacillaris }\end{array}$} & \multirow{2}{*}{$\begin{array}{l}\text { Quercus } \\
\text { lanata } \\
0.38 \mathrm{~ns}\end{array}$} & \multirow{2}{*}{$\begin{array}{l}\text { Ligustrum } \\
\text { confusum } \\
-0.40 \mathrm{~ns}\end{array}$} & \multirow{2}{*}{$\begin{array}{l}\text { Woodfordia } \\
\text { fruticossa } \\
0.84^{*}\end{array}$} & \multirow{2}{*}{$\begin{array}{l}\text { Celtis } \\
\text { australis } \\
0.31 \mathrm{~ns}\end{array}$} & \multirow{2}{*}{$\begin{array}{l}\text { Alnus } \\
\text { nepalensis } \\
0.20 \mathrm{~ns}\end{array}$} & \multirow{2}{*}{$\begin{array}{l}\text { Bauhinia } \\
\text { Variegata } \\
0.43 \mathrm{~ns}\end{array}$} & \multirow{2}{*}{$\begin{array}{l}\text { Lagerstremia } \\
\text { indica } \\
0.17 \mathrm{~ns}\end{array}$} \\
\hline \multirow{3}{*}{ RWC $x$} & $\psi_{\mathrm{sz}}$ & & & & & & & & \\
\hline & $\psi_{\mathrm{sf}}$ & $-0.39 \mathrm{~ns}$ & $0.60 \mathrm{~ns}$ & $-0.34 \mathrm{~ns}$ & $0.79 *$ & $0.13 \mathrm{~ns}$ & $0.05 \mathrm{~ns}$ & $0.21 \mathrm{~ns}$ & $-0.18 \mathrm{~ns}$ \\
\hline & $\varepsilon$ & $0.86^{* *}$ & $0.62 \mathrm{~ns}$ & $0.91^{* *}$ & $0.002 \mathrm{~ns}$ & $0.67^{*}$ & $0.44 \mathrm{~ns}$ & $0.50 \mathrm{~ns}$ & $0.77^{*}$ \\
\hline \multirow{2}{*}{$\psi_{\mathrm{sz}} \mathrm{x}$} & $\psi_{\mathrm{sf}}$ & $0.82^{*}$ & $0.78^{*}$ & $0.91^{* *}$ & $0.96^{* *}$ & $0.95^{* *}$ & $0.96^{* *}$ & $0.93^{* *}$ & $0.85^{* *}$ \\
\hline & $\varepsilon$ & $-0.29 \mathrm{~ns}$ & $-0.38 \mathrm{~ns}$ & $-0.54 \mathrm{~ns}$ & $-0.51 \mathrm{~ns}$ & $-0.46 n s$ & $-0.77^{*}$ & $-0.38 \mathrm{~ns}$ & $-0.36 n s$ \\
\hline$\psi_{\text {sf }} \mathrm{x}$ & $\varepsilon$ & $-0.75^{*}$ & $-0.23 \mathrm{~ns}$ & $-0.57 \mathrm{~ns}$ & $-0.57 \mathrm{~ns}$ & $-0.62 \mathrm{~ns}$ & $-0.85^{* *}$ & $-0.55 \mathrm{~ns}$ & $-0.73^{*}$ \\
\hline
\end{tabular}

*Significant at $\mathrm{p}=0.05,{ }^{* *}$ Significant at $\mathrm{p}=0.01$, ns: non significant

to be slightly more than one year. The deciduous species remained leafless for one to three months (Table 2). In all species buds broke in March and/or April. Among evergreen species, leaf production and shoot elongation were completed in June; thus they retained fully mature leaves during the rainy season. Deciduous species continued to produce new leaves until late rainy season. The marked individuals of Celtis australis were saplings ( $\mathrm{dbh}<10 \mathrm{~cm}$, height $>137$ $\mathrm{cm}$ ) in which leaf production continued until November. In Lagerstroemia indica leaves produced in the first flushing matured in two months; but this species has multiple leafings and produced 2-3 crops of leaves. In all evergreen species, leaf production was completed in two (Quercus lanata) to four (Woodfordia fruticosa) months (Table 2). Leaf fall was most concentrated in Cotoneaster bacillaris, which completed the process in two months.

\section{Water relations parameters}

\section{Evergreen vs. deciduous}

In this study, evergreen and deciduous species differed significantly (ANOVA, p $=0.000$ ) when parameters were considered separately (Table 3) but the difference was not clear when mean values of $\mathrm{RWC}_{\mathrm{z}}, \psi_{\mathrm{sf}}$ and $\varepsilon$ were considered together (Figure 2). Woodfordia fruticosa is an evergreen shrub but resembles deciduous species in most parameters (Table 4, Figure 2). Evergreens had higher $\mathrm{RWC}_{\mathrm{z}}$ and $\varepsilon$ than deciduous species, but $\psi_{\mathrm{sf}}$ and $\psi_{\mathrm{sz}}$ were lower in evergreens. $\mathrm{RWC}_{\mathrm{z}}$ was highest in two evergreen species (Cotoneaster bacillaris and Ligustrum confusum) and lowest in a deciduous species (Celtis australis) (Table 4). Mean $\Delta \psi_{\text {sf }}$ for evergreens was $0.92 \mathrm{MPa}$, compared with $0.64 \mathrm{MPa}$ for deciduous. $\psi_{\mathrm{sz}}$ and $\varepsilon$ did not vary significantly among the deciduous species but the variation of these parameters was significant among the evergreen species. $\Delta \varepsilon$ was $8.26 \mathrm{MPa}$ and $4.87 \mathrm{MPa}$ for evergreen and deciduous species, respectively.

\section{Species level variation}

All evergreen species studied except Woodfordia fruticosa exhibited reduced osmotic potential $\left(\psi_{\mathrm{s}}\right)$ before their leaves flushed out (Figure 3). Cotoneaster bacillaris had the highest mean $\mathrm{RWC}_{\mathrm{z}}$ and the lowest mean $\psi_{\mathrm{sz}}$ and $\psi_{\mathrm{sf}}$ of all species (Table 4). In this species $\psi_{\text {sf }}$ increased (Figure 3A) during bud break (Table 2). Quercus lanata had low $\mathrm{RWC}_{\mathrm{z}}$ and $\psi_{\mathrm{sf}}$ in April (Figure 3B) when the trees were producing new leaves (bud break, Table 2). In April the $\psi_{\text {sf }}$ value for Q. lanata fell by $0.71 \mathrm{MPa}$ from the value recorded for March. During the summer months $\varepsilon$ apparently did not change. Ligustrum confusum, with the highest $\mathrm{RWC}_{\mathrm{z}}$ among all species, reduced 
$\mathrm{RWC}_{\mathrm{z}}$ and $\varepsilon$ to their lowest values in the month of bud break (Figure 3C). In Woodfordia fruticosa $\mathrm{RWC}_{\mathrm{z}}$ was low in March and increased, along with $\psi_{\text {si' }}$ until late summer (Figure 3D). During March $\varepsilon$ decreased by $2.65 \mathrm{MPa}$ from the maximum value $(8.48 \mathrm{MPa})$ recorded in January.

Celtis australis had the lowest $\mathrm{RWC}_{\mathrm{z}}$ among the eight species (Table 4). During April and May, when $\mathrm{RWC}_{\mathrm{z}}$ was decreasing, $\varepsilon$ was low (Figure 4A). In May RWC and $\varepsilon$ both were at their lowest. In Alnus nepalensis, $\mathrm{RWC}_{\mathrm{z}}$ and $\psi_{\mathrm{sf}}$ were high in April but $\varepsilon$ was lowest in the same month (Figure 4B). For the dry period (October to May) $\mathrm{RWC}_{\mathrm{z}}$ was lowest in December, when $\psi_{\text {sf }}$ decreased to the lowest value. During bud break (March, Table 2, Figure 4B) RWC and $\psi_{\mathrm{s}}$ both were increasing whereas $\varepsilon$ was decreasing. Bauhinia variegata also had very low $\mathrm{RWC}_{z}$, in the same range as Celtis australis (Table 4). $\psi_{\mathrm{sf}}$ was lowest in November; after November, it increased until June, apart from a slight decrease in January (Figure $4 \mathrm{C}$ ). In B. variegata, mean $\varepsilon$ and it's June value for $\varepsilon$ were the lowest of the eight species' (Table 4). Lagerstroemia indica had $\mathrm{RWC}_{\mathrm{z}}<80 \%$ except in June (Figure $4 \mathrm{D}$ ). After November $\mathrm{RWC}_{\mathrm{z}}$ decreased until reaching its lowest value in April. From March through May, when $\mathrm{RWC}_{\mathrm{z}}$ was low, $\psi_{\mathrm{sf}}$ was high and $\varepsilon$ low.

The shrubs and trees (Table 4) in this study did not differ significantly $(p>0.05)$ in the measured water relations parameters. Similarly, canopy and under-canopy species differed significantly $(\mathrm{p}<0.05)$ in $\psi_{\mathrm{sp}}, \psi_{\mathrm{sz}}$ and $\varepsilon$ but not in $\mathrm{RWC}_{\mathrm{z}}$ (Table 3). Canopy species had lower $\psi_{\mathrm{sz}}$ and $\psi_{\mathrm{sf}}$ but higher $\varepsilon$ than the under-canopy species. Species with a primary distribution range in the temperate region (2000-3000 masl) had high $\mathrm{RWC}_{z}$, while the other species (except Celtis australis) with their primary distribution range in the subtropical region (1000-2000 masl) had low $\mathrm{RWC}_{\mathrm{z}}$. In contrast to other temperate species, C. australis had the lowest $\mathrm{RWC}_{\mathrm{z}}$ (Table 4) but distributed up to temperate region.

\section{Relations among the parameters}

The correlation between $\mathrm{RWC}_{\mathrm{z}}$ and $\psi_{\mathrm{sf}}$ was significant only in Woodfordia fruticosa (Table 5). The correlation between $\mathrm{RWC}_{\mathrm{z}}$ and $\varepsilon$ was significant in Cotoneaster bacillaris, Ligustrum confusum, Celtis australis and Lagerstroemia indica. $\psi_{\mathrm{sf}}$ increased when $\varepsilon$ declined but the correlation was significant only for C. bacillaris, Alnus nepalensis and L. indica.

Linear regression analysis showed that low $\psi_{\mathrm{s}}$ in our species was associated with high $\mathrm{RWC}_{z}$, although the relation was only marginal $\left(\mathrm{R}^{2}=0.05, \mathrm{p}=0.08\right.$ for $\psi_{\mathrm{sz}} \mathrm{vs}_{\mathrm{RWC}}$; and $\mathrm{R}^{2}$ $=0.08, \mathrm{p}<0.05$ for $\psi_{\text {sf }}$ vs RWC $\left.{ }_{z}\right) . \varepsilon$ appears to be an important parameter which could explain $>50 \%$ of the variation in $\mathrm{RWC}_{z}$ and $\psi_{\text {sf }}$ (Figure 5). Species with less elastic tissue (higher $\varepsilon$ ) had higher $\mathrm{RWC}_{\mathrm{z}}$. Both $\mathrm{RWC}_{\mathrm{z}}$ and $\varepsilon$ were higher for evergreen species than for deciduous. Species with more elastic tissue (lower $\varepsilon$ ) had higher values of $\psi_{\mathrm{sz}}$ (Figure 5).

\section{Discussion}

The studied evergreen and deciduous species all put out their new leaves during the dry months of March and April (Table 2), when day length is increasing and temperatures are rising (Figure 1), bearing the cost of leaf production every year. A one-year leaf lifespan has been observed in
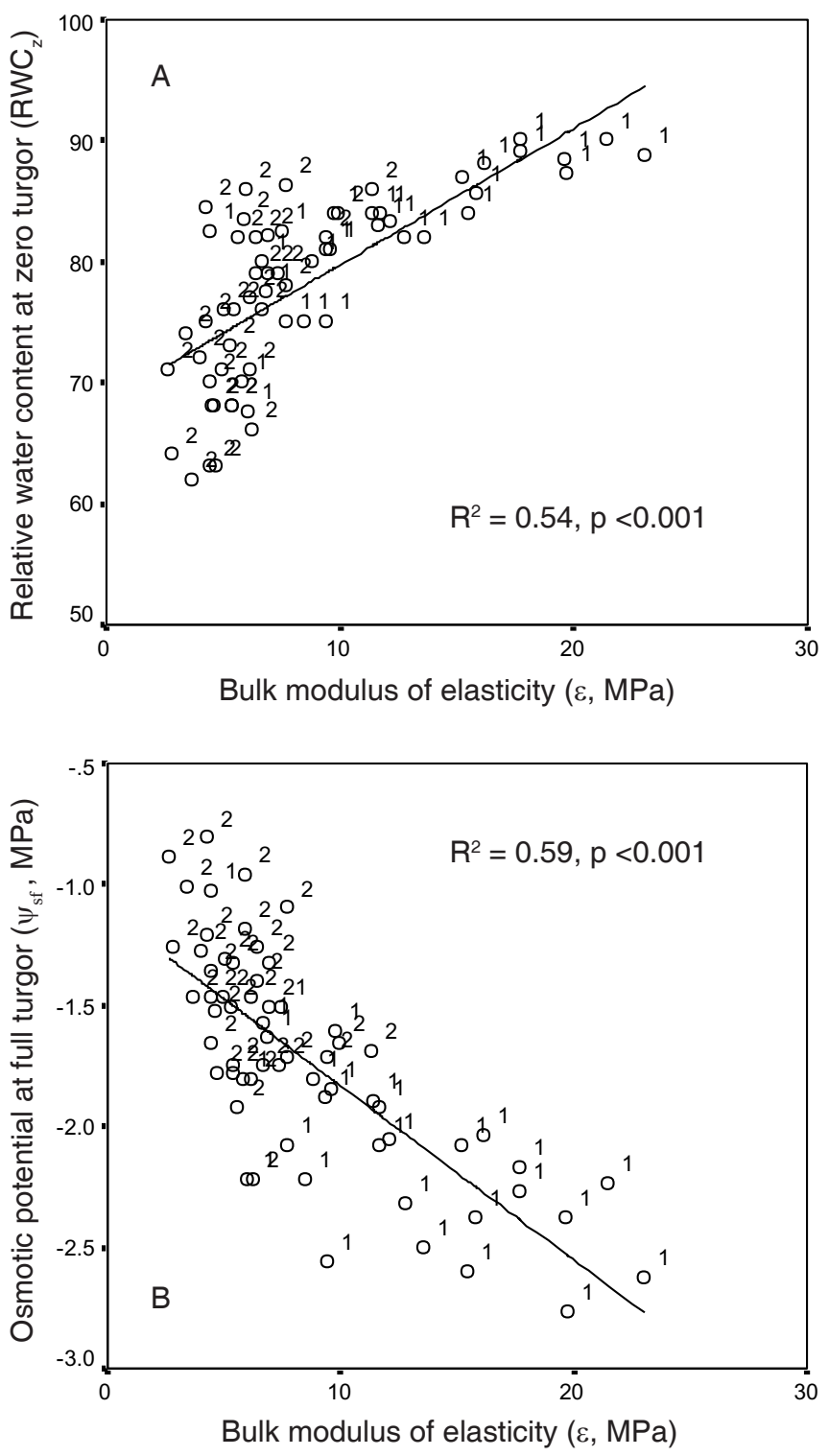

Figure 5. Linear regression of bulk modulus of elasticity against relative water content at zero turgor $(\mathrm{A})$ and osmotic potential full turgor (B); 1: evergreen species, 2: deciduous species

most of the broadleaved evergreen species of the central Himalayas (Ralhan et al. 1985, Poudyal et al. 2004). However, the duration of leaf production is longer in most of the deciduous species than in evergreens (Table 2, Figures 3, 4). Species with a shorter period of leaf production appear to have more concentrated leaf fall. This difference in leaf production may lead to differences between evergreen and deciduous species as concerned many structural and functional traits (Volkenburgh 1999). Due to the prolonged period of shoot elongation and leaf production in the deciduous species, the leaves are widely spaced and fresh new leaves are present throughout the rainy season. This can maximize the photosynthetic rate (Kikuzawa 1995) and may compensate for the short leaf longevity of deciduous species. 
Such a pattern of leaf production is common among most of the early successional species in the central Himalayas (Singh and Singh 1992). The maximum photosynthesis during rainy season may be low in these evergreens, as the rate of photosynthesis declines with the aging of leaves (Kikuzawa 1995). Deciduous species like Celtis australis, Alnus nepalensis and Bauhinia variegata retained $>50 \%$ of leaves during the dry winter season. They may represent a transitional stage between the winter deciduous species of temperate latitudes and the evergreen species of the Himalayas, with leaf lifespan of nearly one year (Singh and Singh 1992).

Deciduous species, which could reduce RWC to lower value before turgor loss, have more elastic tissue and higher $\psi_{\text {sz }}$ and $\psi_{\text {sf }}$ than evergreens (Table 3, Figure 5). This supports the suggestion that elastic cell walls are important for drought resistance in trees (Fan et al. 1994, Lambers et al. 1998) but appears to contrast Davis (2005) who showed that a less elastic cell wall was also important in drought resistant trees. It appears that elastic walls allow tissue to maintain turgor longer as water is lost, while the stiff (less elastic) walls cause $\psi$ to drop quickly as water is lost, increasing the gradient of $\psi$ from soil to leaf and increasing water uptake (DB Zobel, Oregon State Univ., per. comm.). The question seems to be which of these two possibilities is most important in different situations. In general, our evergreen species have stiff cell walls and lose turgor at high tissue water content (RWC, Figure 5A), but they have lower $\psi_{\mathrm{s}}$ than do deciduous species (Figure 5B). Low $\psi_{\mathrm{s}}$ maintains the necessary $\psi$ gradient from soil to plant and promotes water absorption during the dry season. Deciduous species have different strategies; they avoid excessive dehydration by shedding leaves, and also maintain turgidity despite low tissue water content thanks to their elastic tissues.

In Cotoneaster bacillaris, although correlation between $\mathrm{RWC}_{\mathrm{z}}$ and $\varepsilon$ was significant ( $\mathrm{p}=0.01$, Table 5 ), no osmotic or elastic adjustment was apparent during the dry period. However, low $\psi_{\mathrm{s}}$ (Table 4) obviously facilitates absorption of water from soil during seasonal drought. Quercus lanata reduced $\psi_{\text {sf }}$ in April just before leaf flushing, which helped to maintain turgidity for new growth. When $\psi_{\text {sf }}$ is low, plants can maintain turgidity at low $\mathrm{RWC}_{\mathrm{z}}$. Osmotic adjustment of this kind has also been reported in other oaks (e.g., Quercus petraea) where soil drying induced the accumulation of fructose and glucose (Epron and Dreyer 1996). Myrica esculenta, an evergreen understory tree of subtropical to temperate region in the Himalayas, also showed a large osmotic adjustment (1.07 MP) in response to seasonal drought (Shrestha et al. 2007). Osmotic adjustment could enable the plant to maintain turgor at lower water potential $(\psi)$ and continue to absorb water from relatively dry soil (Lambers et al. 1998). In Ligustrum confusum increasing tissue elasticity (or decreasing $\varepsilon$, i.e. elastic adjustment) helped to maintain required turgidity during new growth. Although Quercus lanata and Ligustrum confusum showed osmotic and elastic adjustment, respectively, their high $\mathrm{RWC}_{\mathrm{z}}$ (Table 4) may not allow successful establishment at dry sites (Lambers et al. 1998). Having most elastic tissue of the studied plants (lowest $\varepsilon$ ) and lowest $\mathrm{RWC}_{\mathrm{z}}$ (Table 4), Woodfordia fruticosa has an inherently high tolerance for dehydration.
This inherent capacity of dehydration tolerance is more important than adjustment (Fan et al. 1994). This capacity has enabled Woodfordia fruticosa to grow on dry rocky slopes of river valleys in central Nepal (BBS, per. observation).

Except for Alnus nepalensis, all deciduous species (Table 2) appear to have an inherent capacity to tolerate dehydration, due to their elastic tissue (low $\varepsilon$ ) and low $\mathrm{RWC}_{\mathrm{z}}$ (Table 4); thus they can grow successfully at dry sites (Lambers et al 1998). In deciduous species, water conserved in the tree trunk after leaf fall is an important resource for new growth during the dry period (Borchert 1994a, Shrestha et al. 2006b). Celtis australis and Lagerstroemia indica, both producing new leaves in March, reduced their RWC during dry months by increasing tissue elasticity (Figure $4 \mathrm{~A}, \mathrm{D}$ ). Bauhinia variegata generally had low $\varepsilon$ and $\mathrm{RWC}_{\mathrm{z}}$ (Table 4, Figure 4C), indicating an inherent capacity to tolerate dehydration. The change in $\psi_{\mathrm{sf}}$ and $\varepsilon$ in response to moisture stress was not apparent in $B$. variegata (Figure 4C). Assuming that species in which osmotic adjustment is important reduce $\psi_{\mathrm{s}}$ during drought (Lambers et al. 1998), the deciduous species of this study did not show any osmotic adjustment. This result contrasts with findings of Auge et al. (1998) who reported that in twelve deciduous species high dehydration tolerance was associated with increasing capacity for osmotic adjustment. Due to their inherent capacity to tolerate dehydration (Bauhinia variegata) or to elastic adjustment (Celtis australis and Lagerstroemia indica), the deciduous species (except Alnus nepalensis) were able to thrive at dry sites (Kramer and Boyer 1995). Without this capacity, A. nepalensis is commonly confined to north facing moist slopes (Jackson 1994). Water conserved in tree trunk after leaf fall contributed to a high $\psi_{\mathrm{s}}$ (Borchert 1994b), which might be adequate to begin new growth during the dry summer.

In conclusion, evergreen and deciduous species both sprout new leaves during the dry summer, when day length is increasing and temperatures are rising. Evergreens can reduce $\psi_{\mathrm{s}}$ and maintain a viable $\psi$ gradient from soil to plant, which facilitates absorption of water during the dry season. Elastic tissue in deciduous species is associated with leaf shedding during the dry season; both strategies may help maintain proper plant $\psi$ for new growth during the dry period. One evergreen species (Woodfordia fruticosa) and three deciduous species (Celtis australis, Bauhinia variegata and Lagerstroemia indica) had inherently high dehydration tolerance due to the presence of more elastic tissue. Weak osmotic adjustment was recorded in Quercus lanata, and elastic adjustment was observed in Ligustrum confusum, Celtis australis and Lagerstroemia. indica during drought.

\section{Acknowledgements}

We are thankful to DB Zobel (Oregon State University, Oregon, USA) for his critical comments and suggestions on the first draft of the manuscript.

\section{References}

Auge RM, X Duan, JL Croker, WT Witte and CD Green. 1998. Foliar dehydration tolerance of twelve deciduous tree species. Journal of Experimental Botany 49(321): 753-759

Borchert R. 1994a. Soil and stem water storage determine phenology and distribution of tropical dry forest trees. Ecology 75: 
$1437-1449$

Borchert R. 1994b. Water status and development of tropical trees during seasonal drought. Trees 8: 115-125

Davis KJ. 2005. Comparison of the water relations characteristics of woody plants in western Oregon [M Sc thesis]. Oregon (USA): Oregon State University. $100 \mathrm{p}+$ app.

Engelbrecht BMJ, LS Comita, R Condit, TA Kursar, MT Tyree, BL Turner and SP Hubbell. 2007. Drought sensitivity shapes species distribution patterns in tropical forests. Nature 447: 80-81 doi:10.1038/nature05747

Epron D and E Dreyer. 1996. Starch and soluble carbohydrates in leaves of water stressed oak saplings. Annales des Sciences Forestieres 53: 263-268

Fan S, JB Terence and E Blumwald. 1994. The relative contribution of elastic and osmotic adjustment to turgor maintenance of woody species. Physiologia Plantarum 90: 408-413

Grammatikopoulos G. 1999. Mechanism for drought tolerance in two Mediterranean seasonal dimorphic shrubs. Australian Journal of Plant Physiology 26: 587-593

Hanninen H. 1991. Does climatic warming increase the risk of frost damage in northern trees? Plant, Cell and Environment 14: 449-454

Hsiao TC. 1973. Plant responses to water stress. Annual Review of Plant Physiology 24: 519-570

Iyngararasan M, L Tianchi and S Shrestha. 2002. The challenges of mountain environments: water, natural resources, hazards, desertification and the implications of climate change. Draft background paper E1 (for review by the Mountain Forum). Bishkek Global Mountain Summit 2002

Jackson JK. 1994. Manual of afforestation in Nepal, 2nd ed, Vol II. Kathmandu (Nepal): Forest Research and Survey Center. p 329-824

Kikuzawa K. 1995. Leaf phenology as an optimal strategy for carbon gain in plants. Canadian Journal of Botany 73: 158-163

Kramer PJ and JS Boyer. 1995. Water Relations of Plants and Soils. San Diago (USA): Academic Press. 495 p

Lambers H, FS Chapin III and TL Pons. 1998. Plant Physiological Ecology. New York (USA): Springer Verlag. $531 \mathrm{p}$

Lechowicz MJ and T Koike. 1995. Phenology and seasonality of woody plants: An unappreciated element in global change research? Canadian Journal of Botany 73: 147-148

Mainali KP, R Tripathi, PK Jha and DB Zobel. 2006. Water relations of Shorea robusta in mixed sal forest in the Churiya hills and plain of central Nepal. International Journal of Ecology and Environmental Sciences 32(2): 143-152
Pallardy SG, JS Pereira and WC Parker. 1991. Measuring state of water in tree systems. In: Techniques and Approaches in Forest Tree Ecophypiology. JP Lassoie and TM Hinkley (eds). Boca Raton, FL (USA): CRC Press. p 27-76

Poudyal K, PK Jha, DB Zobel and CB Thapa. 2004. Patterns of leaf conductance and water potential of five Himalayan tree species. Tree Physiology 24: 689-699

Press JR, KK Shrestha, DA Sutton. 2000. Annotated checklist of the flowering plants of Nepal. London: The Natural History Museum. $430 \mathrm{p}$

Ralhan PK, RK Khanna, SP Singh and JS Singh. 1985. Phenological characteristics of the tree layer of Kumaun Himalaya forests. Vegetatio 60: 91-101

Reich PB. 1994. Phenology of tropical forests: patterns, causes and consequences. Canadian Journal of Botany 73:164-174

Shrestha BB, PK Jha and DB Zobel. 2006a. Water relations and phenology of Pinus roxburghii Sarg. in the Churia hills, central Nepal. International Journal of Ecology and Environmental Sciences 32(2): 183-192

Shrestha BB, Y Uprety and PK Jha. 2006b. Wood properties in relation to phenology of some planted trees at Kirtipur, central Nepal. Tropical Ecology 47(2): 201-209

Shrestha BB, DR Luitel, D Lamichhane and PK Jha. 2007. Phenological events and water relations of some trees of subtropical forest. International Journal of Ecology and Environmental Sciences [In press].

Singh JS and SP Singh. 1992. Forests of Himalaya: Structure, Functioning and Impact of Man. Gyanodaya Prakashan, Nainital, India. $257 \mathrm{p}$

SPSS. 2001. Statistical Package for Social Sciences (SPSS), version 11.0. SPSS Inc. USA.

Tewari A. 1998. Timing of drought: Effects on water relations of certain major forest types of lower and middle central Himalaya $[\mathrm{Ph} \mathrm{D}$ Dissertation]. Nainital (India): Botany Department, Kumaon University. $133 \mathrm{p}$

Volkenburgh EV. 1999. Leaf expansion - an integrating plant behavior Plant Cell and Environment 22: 1463-1472

Zobel DB and SP Singh. 1995. Tree water relations along the vegetational gradient in the Himalaya. Current Science 68: $742-745$

Zobel DB and SP Singh. 1997. Himalayan forests and ecological generalizations. BioScience 47: 735-745

Zobel DB, SC Garkoti, SP Singh, A Tiwari and CMS Negi. 2001. Patterns of water potential among forest types of the central Himalaya. Current Science 80: 774-779 